Article

\title{
The Democratic Legitimacy of Secession and the Demos Problem
}

\author{
José L. Martí \\ Department of Law, Pompeu Fabra University, Spain; E-Mail: joseplluis.marti@upf.edu
}

Submitted: 28 June 2021 | Accepted: 24 August 2021 | Published: 10 December 2021

\begin{abstract}
The normative literature on secession has widely addressed the question of under which conditions the secession of a particular territory from a larger state might be regarded as justifiable. The idea of a normative justification of secession, however, remains ambiguous unless one distinguishes between the justice of secession and its legitimacy, a distinction that is now widely accepted in political philosophy. Much of the literature seems to have focused on the question about justice, while, in comparison, very little attention has been paid to the question of under which conditions secession can be regarded as democratically legitimate, as something explicitly different to the question of justice. This article addresses this second question. After some preliminary remarks, the article focuses on the main obstacle to develop a theory of democratic legitimacy of secessions, the so-called "demos problem." Such problem, it is argued, has no categorical solution. This does not imply, however, that there is no democratic, legitimate way of redrawing our borders. Two strategies are proposed in this article to overcome the difficulty posed by the demos problem: an ideal strategy of consensus building and a non-ideal strategy of decision-making in the circumstances of disagreement.
\end{abstract}

\section{Keywords}

all-affected principle; all-subjected principle; consensus; constitution; democracy; demos; legitimacy; referendum; secession

\section{Issue}

This article is part of the issue "Secessionism in Liberal Democracies: What Do We Really Know About the Explanations of Secessionism?" edited by Ferran Requejo (Pompeu Fabra University, Spain) and Marc Sanjaume-Calvet (Pompeu Fabra University, Spain / Open University of Catalonia, Spain).

(C) 2021 by the author; licensee Cogitatio (Lisbon, Portugal). This article is licensed under a Creative Commons Attribution 4.0 International License (CC BY).

\section{Introduction}

The normative literature about the justice of secession is extensive and diverse. Nationalist theories (e.g., Kymlicka, 2001; Miller, 1998, 2003; Moore, 1997), remedial theories (Buchanan, 1991, 1997), plebiscitary theories (Beran, 1984; Philpott, 1995; Wellman, 2005), and mixed theories (Bossacoma, 2020; Catala, 2017; Lefkowitz, 2008, 2018; Patten, 2014; Weinstock, 2000, 2001) have all tried to answer the question of under which circumstances we might regard the secession of a particular territory from a larger state to be justifiable. This idea of a normative justification of secession, however, remains ambiguous unless one clearly distinguishes between the justice of secession and its legitimacy, a distinction that is now widely accepted in political philosophy. This literature on just secession has been regarded as a special case within the larger literature on self-determination and territorial rights (e.g., Brilmayer, 1991; Stilz, 2018). Surprisingly, very little has been said about the legitimacy of secession. It is true that some of the theories of secession, especially the plebiscitary ones, have been casted in terms of a consent-based notion of authority. Even in those cases, it is not clear if the principles they invoke are really incompatible with the views defended by those who have focused on the justice of secession, that is, it is not clear to what extent they are all participating in the same debate and really discussing each other's claims. In most cases, the notions of justice and legitimacy are conflated, or treated as equivalent or synonymous, or they are not sufficiently distinguished (e.g., Dalle Mulle \& Serrano, 2018; Pérez, 2021; Pérez \& Santjaume, 2013; Santjaume, 2020). And yet, these two notions refer to two very different questions. 
This article aims at providing a preliminary theory of the legitimacy of secession, and more particularly a democratic one. The main claim of such theory is that secession is legitimate insofar as it is democratically agreed or decided. This broad claim is compatible with very different understandings of what may count as a democratic agreement or decision, and, even more relevantly, with diverse views about who should decide or agree on the secession of a particular territory, in other words, with which is the relevant people or demos to the effect of the democratic legitimacy of that secession. This last issue is what in the literature has been often called the demos problem (Dahl, 1970, 1991) or, more recently, the boundary problem (Arrhenius, 2005), and it is often regarded as a problem or dilemma that democracy itself is not able to solve (Schumpeter, 1942, Chapter 20). This does not imply, however, as Joseph Schumpeter famously assumed, that democratic legitimacy should be indifferent to any form of determination of the demos. As I will argue, there is no categorical or knocking-down argument by virtue of which we can settle a democratic solution to the demos problem. However, this fact has important practical implications for the way we can democratically approach real territorial conflicts.

One of my assumptions is that there might be certain conditions under which the secession of a territory from a larger, existing state may be just and legitimate. If, alternatively, we presumed that all secessions are always unjust and illegitimate no matter what and took our borders to be unalterable, we would be giving the status quo a preeminence that it does not deserve, especially considering that such status quo has emerged mostly in an arbitrary way. I do not think this view is plausible, but I will not argue for this here. Let me just take for granted the premise that borders might, under some conditions, be redrawn in a just and legitimate way throughout processes of integration, supercession, or secession.

There is another preliminary issue that I should clarify. Much of the literature about just secession is casted in terms of whether there is a right to secede or not. Powerful as it often is, the language of rights might be of little help here. First of all, since my main focus in this article is the political morality of secession, the legalistic language might be confusing. I will not say anything for instance about whether, as a matter of fact, there is a legal right to self-determination recognized by international law that might support the aspirations of certain secessionist movements under certain circumstances. The language might be confusing because it might give the impression that if $x$ has a right to secede from $y$, at least in some circumstances, this means that $x$ might unilaterally exercise such a right without further agreement or negotiation with $y$, which is, as we will see, hardly the case. And it might also give the impression that from the claim that $x$ has a moral right to secede from $y$ in circumstances $c$, we can infer that $x$ should have a legal or constitutional right to do so. But this of course does not follow. The legal discussions about international law (see for instance Lefkowitz, 2018) or about the constitutionalization or legalization of a right to secede (Sunstein, 1988; Weinstock, 2001) are at least partially independent from the issues of political morality on which I will focus in this article that determine under which circumstances secession might be permissible.

In the next section, I will start by distinguishing between justice and legitimacy to pave the way for my argument in the rest of the article. In Section 3 I will present the main claim of the theory of democratic legitimacy of secession and the demos problem that emerges from it. I will also analyze the two main normative principles that have been proposed to solve this problem, showing that none of them provides a real solution to it in a case of potential secession. This will allow me to distinguish between two different questions behind the demos problem: the question about the boundaries of an undisputed demos and the question about the sovereignty of the central demos. I will argue that we do lack a categorical or knocking-down argument to settle disputes in this second type of problems. In Section 4, however, I will outline two different strategies, one ideal and one non-ideal, to deal with the central demos problem and its implications, which may ground a theory of the democratic legitimacy of secession. In Section 5, I will summarize the main points of the article.

\section{Justice and Legitimacy in Normative Political Philosophy}

Most contemporary political philosophers (from Rawls and Habermas, to Dworkin, Pettit, or Christiano) distinguish between justice and legitimacy. There is widespread agreement today that normative political philosophy actually divides into these two realms, even if philosophers usually differ in the concrete way of conceptualizing each of them (for a thorough and straightforward distinction, see Pettit, 2012, Chapter 1).

Both justice and legitimacy are approached here in their normative dimension. Political scientists and sociologists often refer to legitimacy in a different sense, in the Weberian, descriptive sense of legitimation. This descriptive sense of legitimacy is associated to how the people, as a matter of fact, perceive the acceptability of their governments or political institutions. Normative legitimacy, instead, settles the normative standard against which those people's subjective perceptions should be assessed. Legitimacy and justice, and this normative sense, refer to how political institutions should be or ought to be, and not to how they are or how they are perceived.

Even if both are normative, justice and legitimacy refer to different dimensions of political morality and it is crucial to distinguish them well. The best way to understand the contrast between them is to see that they aim to answer two different normative questions (Martí, 2017). The question that justice aims to answer 
is the question of what should be done on a substantive level by political institutions or political regimes. Thus, a just political regime or institution would be one whose decisions are the correct ones from the point of view of substantive political morality. A correct decision is (the) one the content of which is regarded as acceptable from the point of view of normative political morality, and different theories of justice will provide different answers to the question of what should be done in a particular situation and context. For the case of secession, a theory of justice will answer the question of under what conditions the secession of a particular territory from a larger state will be substantively justified. And different theories of just secession, as the ones I mentioned in the introduction, will provide different answers to that question. A typical structure of a theory of just secession will be the following one: "If conditions $a, b, c$, obtain, then the secession of territory $x$ from the larger state $y$ is morally justifiable," where $a, b$, and $c$ stand for different normative requirements, $x$ for the seceding territory previously identified according to some other criterion, and $y$ stands for the state from which $x$ might be morally permitted to secede.

The question that legitimacy aims to answer is a different one. Legitimacy is concerned with who and how should make certain political decisions, and not about which decision or decisions are the correct ones. In that respect, the question that legitimacy aims to answer is eminently procedural. This does not exclude the possibility that such standard may have some substantive requirements. Most philosophers, like Rawls, Habermas, Dworkin, or Pettit, actually include, for instance, the general respect for basic human rights. But the central question of legitimacy has to do with who and how should make decisions, and this is a procedural question. As with justice, legitimacy settles a standard of normative political morality against which political institutions or regimes, or even concrete political decisions, may be assessed. In that sense, a political institution is legitimate if it is the authority that has the right to make certain decisions or the right to rule in a particular context. And a concrete political decision may be legitimate if it has been made by the right body and through the right procedure. This is why legitimacy is intrinsically connected to the concept of authority and through this to the issue of political obligation. The normative discussion about the notions of legitimacy, authority, and political obligation is huge, and different theories have been proposed to make sense of them (Christiano, 2013; Dagger \& Lefkowitz, 2014). Giving a proper account of them would exceed the limits of this article, and it is not actually relevant to the central point that I want to focus on in the next section.

It is easy to see why legitimacy matters. First of all, we happen to disagree greatly about what justice requires, and we need a more operative and less controversial concept of moral acceptability that might be agreed upon by people with different perspectives on justice. And, sec- ond, even if we happened to agree entirely on justice issues, we still would need someone or some body to make the political decisions that apply to us, and who and how they make them is not, for different reasons that I will not develop here, morally irrelevant. As a matter of fact, as I will show in the next section, there is wider agreement on issues of legitimacy. And still, we disagree on legitimacy as well. Different theories of legitimacy will provide different answers to the question of who and how should make the political decisions that bind us all. For the context of secession, a theory of legitimate secession will answer the question of who and how should decide about the secession of a particular territory from a larger state in order for this decision to result acceptable from the point of view of political morality. A typical structure of a theory of legitimate secession will be the following: "the secession of territory $x$ from the larger state $y$ is legitimate if and only if the decision of seceding has been made by $D$ through procedure $P$ and additional conditions $a, b, c$, obtain," where $x$ stands for the seceding territory, $y$ stands for the state from which $x$ might secede, $D$ stands for the people or body who must make the decision, $P$ stands for the proper procedure through which such decision must be made, and $a, b$, and $c$, stand for the different additional requirements that might be imposed by political morality.

As I said above, justice and legitimacy aim to answer different questions, but this does not mean that their answers are totally disconnected from each other. What is crucial in distinguishing them is to understand that a particular political institution or a particular political decision might be just and illegitimate, or legitimate and unjust, at the same time. They might also be, of course, both unjust and illegitimate, or finally just and legitimate, which would be the optimal case. When we address the normative acceptability or justifiability of a particular secession from the point of view of political morality, we should be concerned about the justice of that secession, as well as about its legitimacy. And it follows from that that a secession that is just but illegitimate, or one that is legitimate but unjust, are cases of secession that are at least partially inacceptable from the point of view of normative political morality. Having said that, it is on the question of legitimate secession that I focus in this article, leaving aside the question about justice.

\section{The Democratic Legitimacy of Secession and the Demos Problem}

\subsection{The Claim of Democratic Legitimacy in the Case of Secession}

Most contemporary theories of political legitimacy adopt a democratic view when answering the question of who and how should make political decisions (Christiano, 2013; Pettit, 2012). This is not equivalent to say that all decisions must be democratic in the sense that they must all be made by the people themselves or by their elected 
representatives. In any democracy there is room for certain types of public decisions that are to be taken by non-elected officials, including some that are independent from the representative bodies, such as the judicial ones or the decisions made by central banks. These are, however, justified exceptions to a general framework of democratic legitimacy that is widely accepted when applied to political regimes as a whole. There is of course disagreement within democratic theory. Internal central debates such as the debate between intrinsic versus instrumental justifications, the debate about political representation and forms of citizen engagement, or the debate between democracy and technocracy, are meaningful only in the context of this generalized consensus in favor of democratic legitimacy (Christiano, 2013, 2015). Not everyone agrees on the centrality of democracy for political legitimacy either. It is not the purpose of this article to argue for such a democratic conception of legitimacy. The debate on whether and why democracy is the best source of political legitimacy is, again, huge and complex. I will simply take for granted that political legitimacy must be, partially or entirely, based on democratic decision-making, because the central problem I want to discuss in this article, the demos problem, only arises for those who endorse such a democratic conception.

There are as many views of democracy as justifications of it. I do not need to take stance here in favor of any of them, since, from all these views, what I will call the main claim of a democratic theory of legitimate secession can be supported. That claim is the following:

The secession of a particular territory from a larger state is legitimate insofar as it has been democratically decided or agreed by the people and certain additional conditions obtain.

This claim leaves many questions open, as I will immediately show. But expressed in these broad terms, I take it to be quite a platitude. What could be a legitimate alternative? One might think that a legitimate decision of secession should be taken by a commission of experts (economists, historians, lawyers, sociologists, etc.). But there is no element in the claim of democratic legitimacy that turns to be incompatible with getting experts involved in the decision-making. Not involving them would be clearly irrational. The only thing that would be incompatible with democratic legitimacy is to ask this commission of experts to make such a consequential decision without any previous act of popular delegation of power, or at the very least any form of ex post democratic supervision or control. I do not know of any case in which something like this has been even proposed. And I cannot think of any reason why that should be the case. The same happens with another alternative that would consist of relying on a third party, for instance a third country. Again, getting third parties involved in territorial conflicts as facilitators or mediators is certainly not incompatible with the view of democratic legitimacy, unless what we do is letting such third country or body or person make the decision of secession by itself with neither previous popular delegation of power nor ex post popular control. But how could we justify that? That would be an act of domination by such third party. Since none of this seems plausible to me, I will simply take for granted that some version of the claim of the democratic legitimacy of secession, as it is widely agreed, must be true.

On the other hand, consider the theories of a just secession that I mentioned above. It is obvious that this democratic claim is essential to the so-called plebiscitary theory of secession. This plebiscitary theory might indeed be interpreted as a theory of just secession or plainly as a theory of legitimate secession. If the latter, it could be seen as a specification of the broad claim I formulated above, but then it is not obvious why should it be a theory alternative and incompatible to the theories of just secession. Regarding these other major theories of just secession, such as the remedial, the nationalist, or the mixed views, all I need to say is that they are also fully compatible with the claim of democratic legitimacy. One thing is that, for instance, according to the remedial theory, the recent history of massive human rights violations might be one of the conditions that might justify a decision of secession from the point of view of its justice, and quite a different thing would be to say that secession is morally mandatory or that it is irrelevant who and how makes that decision. The same logic applies to the so-called nationalist theories. You may think that only nations, identified according to certain notion of nationhood, and under the right circumstances, have the right to secede. But, again, this does not mean that they have the obligation to do it. Someone must make the decision-or omit to make it-and legitimacy, as we saw in the previous section, must provide an answer to the question of who and how that person or body should be.

The deliberately broad terms in which I have formulated the claim of democratic legitimacy of secession leaves, as I said above, many questions open. For instance, what does it mean for a decision to be democratically decided? In other words, which exact procedure of decision-making $P$ should be followed? Should it be decided necessarily through a referendum, as many theorists of secession often argue? Or could a parliamentary decision or even a presidential decision be enough? Would such decision require in all cases a constitutional reform? Should we necessarily have a negotiation between $x$ and $y$ about the terms of in which secession will take place in order to make it legitimate? Should courts at some level have some kind of control over the decision? Or what additional conditions should be obtained in order to make the democratic decision fully legitimate? Should we only grant that basic human rights are not violated or should we add other formal or substantive requirements? Central as they are, I will leave all these questions aside in this article, and I will focus on the main question that immediately arises from 
this democratic claim: Who is the relevant people that must make the legitimate decision of secession? This question might seem unproblematic to many, but it actually leads us to a very serious problem: the so-called demos problem.

\subsection{The Demos Problem}

Who is exactly the people or demos that should make the decision of secession for it to be legitimate? Should it be the people of the seceding territory $x$ or the people of the larger state $y$ ? And how can we identify $x$, in the first place? This is the so-called demos problem or paradox (Dahl, 1970, 1991), also known as the boundary problem (Arrhenius, 2005), and it has been largely ignored by democratic theory over the centuries until very recently. The problem, simply put, is that democracy takes for granted the existence of a particular, preexisting demos. It is the people who belong to that demos who should govern by themselves according to the idea of democracy. In Lincoln's famous words, democracy would be the government of the people, by the people, and for the people. But what can we do when the sovereignty of the existing demos is at question, as it precisely happens in the case of secession, or when the boundaries of it are far from clear?

From a nationalist point of view, it might seem that the answer is obviously the demos of the seceding territory $x, D_{x}$, as long as $x$ can be identified as a separate nation. This, however, is deeply problematic. Let me use the example of Catalan secessionism to illustrate that point. The historical secessionist movement in Catalonia used to identify the Catalan nation with those territories where the Catalan language was vernacular, the so-called "Catalan countries," which included modern Catalonia, as well as parts of Valencia, Aragon, the Balearic Islands, and Southern France. In the case of an eventual Catalan secession, would $x$, the seceding territory, be all those Catalan Countries? Quite strategically, many secessionists have nowadays given up that idea and they mostly claim that it is modern Catalonia, where the percentage of secessionists is clearly greater, the only territory that should secede from Spain (or from France, for that matter). But why is it so? If the criterion to identify the demos, $D$, is based on a nationalist account, there is no clear boundary between modern Catalonia and certain other Catalan countries. Any boundary we draw seems to be arbitrary. What is more, there is at least one territory within modern Catalonia, the Aran Valley, where people speak a different vernacular language, many of them conceive themselves as a separate nation, and there is a clear majority against the independence of Catalonia from Spain. Should they be part of $x$, the territory that is eventually seceding? How can we determine the exact boundaries of $x$, when nationalism does not provide an accurate concept of nation? Even if we found a non-arbitrary way to determine the boundaries of $x$, why should the people of $x$ be the relevant demos, $D$, to make a legitimate decision about the secession of $x$ ? Why is it not the people of $y$, the larger state, the relevant $D$ to the effect of making such a legitimate decision, or even the people of larger political units to which $y$ is part, like the European Union (EU)? Again, it is not easy to find a no non-arbitrary criterion to establish $D$, and democracy does not seem to be of any help.

As Joseph Schumpeter early stated (Schumpeter, 1942 , Chapter 20), the problem is that for conceptual reasons the relevant demos $D$ cannot be democratically settled. A democratic decision establishing certain boundaries of $D_{1}$ can only be non-arbitrary, and therefore legitimate, if the demos that makes such decision, $D_{0}$, is itself legitimate and non-arbitrary. If $D_{0}$ were arbitrary, all decisions made by that demos would be illegitimate. But that, of course, is just the beginning of an infinite regress. At this point, the demos problem converges into the wellknown democratic paradox. If legitimacy is equated with democracy, since democracy has at some point been created necessarily by non-democratic means-for there was no democracy before the creation of democracyan unavoidable implication seems to be the establishment of any democracy is not legitimate in the first place. There is, apparently, no procedural way out from this conundrum-although I will attempt one at the end of this section. Therefore, contemporary democratic theory, much under the influence of Robert Dahl, has tried to identify a non-nationalist substantive principle that might allow us to identify $D$, or at least $D_{0}$, in a procedureindependent way. Let me analyze the two most prominent substantive principles that have been proposed.

The most popular principle of determination of the demos is the all-affected principle. In the words of Dahl himself, "everyone who is affected by the decisions of a government should have the right to participate in that government" (Dahl, 1970, p. 64; see also Arrhenius, 2005; Brighouse \& Fleurbaey, 2010; Dryzek, 2006; Goodin, 2007; Habermas, 1992; König-Archibugi, 2017). There are two major problems with this principle. First, we have an epistemic problem. Different people might potentially be affected by a decision in different ways, at different levels, and in different moments, and we may have serious, perhaps fatal, difficulties in determining in advance who may end up being affected by a decision in the mid and long term. The solution might be to acknowledge that the affectedness condition may come by degrees and that everyone in the world, including the present as well as the future generations, can be potentially affected by any decision. For some, this works as a reductio objection against this principle. For others, it just shows that we have reasons to favor some form of global democracy (Dryzek, 2006; Goodin, 2007). In any case, if we apply this principle to the case of secession we may end up with an unrealistic conclusion. It is obvious that the secession of territory $x$-let us say, Catalonia-from the larger state $y-$ Spain - affects both the people of Catalonia and Spain. 
It might seem, then, that the relevant demos to make a legitimate decision should be the Spanish one. But the rest of the member states of the EU would also be clearly affected, since this would imply an alteration of the EU's treaties, institutions, and borders. Should $D$, the demos that has to make the secession decision in Catalonia, be integrated by the population of all EU member states? What about other neighboring countries, such as Andorra, Switzerland, or Morocco, whose interests could also be affected? What about other more distant countries that might be strongly connected to Catalonia or Spain, such as the USA, or many countries in Latin America? Should all participate in the decision about the potential secession of Catalonia? It does not seem very plausible.

The main alternative to the all-affected principle is the all-subjected principle, according to which all the people who are legally bound or subjected to a decision should participate in making such decision (Abizadeh, 2008; Beckman, 2014; López-Guerra, 2005). There are two obvious problems with this second view. First, the notion of legal subjection or bindingness is ambiguous. One might think that being legally bound or subject to a particular political decision means having to face the legal consequences of such decision. But who has to face the legal consequences of an eventual secession of Catalonia from Spain? All Spaniards would definitely be subject to that decision and face its consequences. But so would the rest of European citizens, since, again, the EU treaties, institutions and borders would be immediately altered. The same problem applies to cases when foreign visitors have the legal obligation to obey at least certain local legal norms, such as the criminal code. There is no doubt that they are legally subject to the local criminal code. Should they have participated in the decisionmaking process that enacted it? One strategy to avoid this problem is to understand the notion of legal subjection in stricter terms, and consider subjected only the people that the concrete norm or decision, or the legal system to which it belongs, identifies as legally bound by it. But this brings us to the second problem. The all-subjected principle interpreted this way is obviously circular. The only way to determine the relevant demos, $D$, for a particular political decision would be to anticipate which would be the people legally bound by such decision. This means that only the relevant people may determine who the relevant people are. But how can we know who is the relevant people in the first place? The only way to avoid the circularity here would be to refer to a previous norm in the same legal system. But that solution to the problem of circularity comes at the cost of generating a new infinite regress. Imagine, again, how this principle could be applied to a particular case of secession. The people of the seceding territory $x$ might make the decision of seceding from $y$ and establish that the relevant people, $D$, is the people of $x$, because they are the ones legally subject to that decision, simply ignoring the other effects that such decision might imply for other people. But since the people of $y$ at large are, according to this, unbound by such decision, nothing would prevent them from making an opposite decision reaffirming the territorial unity of $y$, and banning the secession of $x$. Both decisions are made by the people who are legally subject in strict terms to each of them, but they are of course contradictory. Which of them is the legitimate one?

None of these two principles, or any other of their alternatives, can solve the demos problem regarding cases of secession. The reason is that they are not designed to do so. These substantive principles are indeed intended to solve a different kind of problem: namely, to answer the question of who should be allowed to participate in a particular decision when general sovereignty is not at stake. Despite the problems they may have, some of which I have mentioned above, they may be useful for instance to give orientation to the question of who should vote in a particular local referendum or who should be enfranchised in a certain election, when there is no fundamental quarrel about who is the sovereign people at large. Take the debate on enfranchising long-term immigrants or the one on banning the disenfranchisement of prisoners in the US or the UK. What we have in those cases is a demos $D_{1}$ taking into consideration whether these two collectives should be enfranchised. In the deliberation they may use substantive arguments based on the all-affected principle or the all-subjected principle or any other alternative principle of inclusion to support such enfranchisement. Thus, $D_{1}$ may incorporate through a democratic decision those social groups into the demos, with the result of expanding it into demos $D_{2}$. If $D_{1}$ has good substantive reasons to do so, that means that $D_{1}$ has been not fully legitimate in the past, since it has operated in exclusion of those two social groups the inclusion of which has been considered now democratically required. It is important to notice, however, that legitimacy is not an all-or-nothing property of governments or political institutions. It is rather scalar. Governments, institutions, and political decisions may be more or less legitimate or illegitimate. The fact that we have good democratic reasons to expand $D_{1}$ into $D_{2}$ by incorporating two social groups does not make the government or the decisions taken by $D_{1}$ totally illegitimate. They make the decisions made by $D_{2}$ prima facie more legitimate, but not necessarily perfect either.

This offers an interesting solution to Schumpeter's procedural problem of infinite regress. A demos can make from time to time a self-referential decision that changes its boundaries increasing or decreasing its legitimacy, its right to rule in a particular territory. There is hardly ever a foundational demos, $D_{0}$, starting from scratch. Even foundational constitutional decisions, such as the signature of the federal US Constitution in 1787, are usually ratified by some people(s) -in the case of the US, by the states that had previously seceded from Great Britain, and in the case of those states individually, by the peoples established in those territories more or 
less well demarcated-with some degree of legitimacy. Legitimacy never goes from zero to one in one decision. One may actually see part of the history of democracy as an ongoing project of enfranchising more and more people. And principles such as the all-affected principle and the all-subjected principle have proven very helpful to strengthen that trend. But they offer no solution when it is the sovereignty of the ultimate relevant demos, $D$, what is precisely at stake. They might be rightly regarded as principles that aim to solve the boundary problem, rather than the central demos problem, when the central idea of sovereignty is disputed. If we stick to the status quo and presuppose that the sovereign relevant demos in a case of secession is the one of the larger state $y$, then all the citizens of that state should participate in the decision about the eventual secession of $x$. But if the citizens of $x$ presuppose that they should be sovereign to make a decision about their eventual secession from $y$ by themselves, then it would be only them the ones that would conform to the relevant demos $D$. The problem is that in both cases they would be begging the question. What we have is two different demoi competing to be the sovereign one. Giving precedence to one of them over the other seems arbitrary.

Secessionists usually claim that it should be the people of the seceding territory $x$ the only relevant demos to make a decision of secession, and the argument they offer is the value of self-government or selfdetermination. The problem with that claim is that the value of self-government presupposes that you have previously identified a sovereign "self," and this is precisely what the decision of secession-for instance, through a referendum of secession-should establish. The sovereign demos $D_{x}$ does not preexist to a legitimate decision of secession. It is constituted by it. Secessionists usually use the metaphor of a divorce. When two individuals want to put an end to their marriage, most legal systems do not require mutual consent. Just the individual will of one of the spouses is enough. Let us leave aside that not all legal systems do the same, and that the regulation of other situations that fall closer to that of secession, such as two partners in a society that break up and split the society, does not acknowledge such unilateral right. The important point is that in contrast to the example of a divorce, where the autonomy or sovereignty of each of the spouses is not at stake, in the case of a secession this is precisely what needs to be decided. The content of a legitimate decision of secession is no other than the establishment of a new sovereign demos. Presupposing the previous existence of such sovereign demos $D_{x}$ would be arbitrary, since no legitimate decision has been made yet. All that we have before such decision is the status quo, that is, the existence of the demos of the larger state, $D_{y}$, which is presumably partially legitimate. The difficulty, of course, contrary to a case of boundary problem, is that in a case of secession it is precisely the legitimacy of $D_{y}$ 's sovereignty what is being challenged. Again, it would be begging the question, and therefore arbitrary, to simply give priority to the status quo. And the scalar approach supported by substantive principles that has proven useful to overcome Schumpeter's difficulty of procedural infinite regress does not seem of any help here.

I have distinguished two variants of the demos problem. One emerges in those decisions that aim to redraw only the internal boundaries of an existing demos, the sovereignty of which is not fundamentally at stake. Following much of the literature, I propose to call this first variant the boundary problem (see, for all, Arrhenius, 2005). And we have several substantive principles that may help us to find a legitimate solution to that problem. The second variant emerges in a totally different type of decisions, where it is the sovereignty of the existing central demos what is precisely being challenged, and the external borders of the territory where such demos is supposed to be sovereign are questioned. I propose to call this second variant the central demos problem. Regarding this, we seem to be trapped in a sort of paradox or dilemma, and there is apparently no argument able to categorically determine who is the relevant demos, $D$, in a case of secession, where it is the sovereignty of the existing central demos what is at stake. Does it mean that we should abandon the democratic theory of legitimate secession? Should we give away the idea of redrawing our borders in a democratic way? That would be throwing the baby out with the bath water.

\section{Democratic Redrawing of Borders}

Even if there is no categorical or knocking-down argument to solve the central demos problem, that does not mean that we should give up the possibility of establishing certain conditions for a democratically legitimate secession. In this section I will propose two ways in which we may do that: I will call them respectively the ideal strategy and the non-ideal one.

Let me start with the ideal strategy. Firstly, we should treat the case of secession as a special case within a wider category, namely, the general case of redrawing state borders, which includes cases of integration, supercession, and secession, among others. This will help us to find a more fruitful and democratic approach, consistent to the one we normally use in the other cases of redrawing borders. Consider the case of integration, which I take to be an easy case for democratic legitimacy. Two states, $a$ and $b$, are considering integrating or merging with each other. Who is the legitimate authority to make such a decision of integration? If one adopts a democratic view of legitimacy, as I do here, it is obvious that it should be the people of both existing states. To be more precise, there should be, first, a decision made by $D_{A}$ and another one made by $D_{B}$, following the right procedure $P$, and then the representatives of both states should sign an agreement or treaty of integration. In the case of supercession, a state $c$ integrates into a larger state $D$, without constituting a new state. Also in this case, we could 
agree in that the democratically legitimate authorities to make that decision are, respectively, the peoples of $c$ and $D$, since, we may assume, caeteris paribus, no people should be forced to be part of a different state or accept a new addition in its own state against its will. In all these cases a veto from any of the existing demoi would be enough to stop the process of integration or supercession, at least regarding that particular demos. These are easy cases because the sovereignty of $a, b, c$, and $D$ is not disputed, and this makes a difference with the case of secession. Because of the central demos problem, and in contrast to the two easy cases, we may conclude that the would-be demos of the eventually seceded territory, $D_{x}$, has no authority to impose (unilaterally) its will for secession to the demos of the larger state, $D_{y}$. The reason is that granting $D_{x}$ the sovereignty required to have such authority would be begging the question, and therefore arbitrary. However, and for the same reason, we shall conclude that the demos of the larger territory, $D_{y}$, has no authority to impose (so to speak, unilaterally) its will on the demos of territory $x, D_{x}$, if it is the case that such demos wants to secede. Let me be clear: $D_{y}$, assuming $y$ is a democratic state, has authority to make general political decisions, including those relative to the boundary problem. But they lack the sufficient authority to make a unilateral decision in order to prevent $x$ to secede, since that sovereignty is precisely what is being challenged, and the existing borders are all arbitrary.

Having said this, let us imagine that there is an agreement between both demoi, $D_{x}$ and $D_{y}$, about the secession of $x$ from $y$. The people of both territories agree that the people of $x$ should be allowed to secede if they want. What could be the problem, then, from the point of view of democratic legitimacy? I cannot imagine an argument to say that something that is voluntarily and democratically agreed by both potentially sovereign demoi-assuming that human rights are not and will not be violated and the other normal conditions obtain-is illegitimate. This is, in my view, the ideal scenario; one that offers no doubt from the point of view of democratic legitimacy. One may wonder how unrealistic it is to expect such ideal scenario to occur. But in my opinion this is exactly the scenario that has taken place in Quebec, Scotland, and New Caledonia, among other cases. Remember that I have said nothing about which is the procedure $P$ that the peoples involved should follow in order to make their decisions legitimate. There are variations regarding this issue. In the cases of the UK and France, there was a previous authorization either by the Prime Minister or the National Assembly of the referendum in Scotland and New Caledonia. In the case of Canada, and according to the criteria identified by the Canadian Supreme Court, there was the need of an ex post negotiation with the Federal Government in addition to the generic permission by the Canadian constitution. In these three cases there was some kind of agreement by the peoples of $D_{x}$ and $D_{y^{\prime}}$, and it was finally the will of $D_{x}$ not to secede what prevented secession to hap- pen, precisely on the basis of democratic legitimacy considerations. Thus, I claim that this ideal scenario is not so unrealistic as it might look.

But what can we do if we are not in the ideal scenario, if there is no agreement between $D_{x}$ and $D_{y}$ ? Taking the demos problem seriously implies that we should maintain that none of them has the legitimate authority to impose unilaterally its will to the other. All what they can do is to keep deliberating and negotiating in good faith in order to try to reach an agreement. But what if one of them, typically the people of the larger existing state $D_{y}$, refuses to negotiate and simply blocks the situation forever? That would be democratically illegitimate. Prima facie, it would be as illegitimate as the people of $D_{x}$ declaring the independence and seceding from $y$ against the will of $D_{y}$. This is what follows from acknowledging the existence of the central demos problem. We might then develop a totally different non-ideal approach to the conflict that should consist in comparing the two illegitimate alternative scenarios, the two evils, so to speak, to try to measure which of them would be worst from a democratic perspective. Here a number of other variables would be relevant. As a way of an example, even if numbers is not the only variable to take into account, they are definitely relevant. Consider scenario 1 in which the people of $D_{x}$ wants to secede by a majority of $90 \%$ and with a very strong or intense preference, while the people of $D_{y}$ opposes that secession only by a majority of $52 \%$ and with a mild preference. The illegitimacy of $D_{y}$ blocking an agreement of solution for the conflict and forcing a large majority of people in $x$ to be part of a state against their will seems to me, caeteris paribus, greater than the illegitimacy of $D_{x}$ unilaterally imposing its will. Now compare this first scenario with a second one in which the numbers are just the opposite: $90 \%$ of $D_{y}$ rejecting the secession of $x$, while only a bare majority of $52 \%$ of $D_{x}$ favors secession. Here it seems that imposing a secession would be, from a democratic point of view, much more illegitimate than remaining in the status quo. As I said, the number of variables to consider in this non-ideal approach is high, and developing a thorough analysis of how it might work exceeds by far the possibilities of this article.

\section{Conclusions}

In this article I have tried to provide a preliminary theory of the democratic legitimacy of secession. This is an attempt to fill the gap in the existing normative literature on secession, which has disproportionately focused on the issue of justice, rather than the legitimacy of secession. I have claimed that the right approach to the problem of the legitimacy of secession is the democratic one, since I am unable to find a plausible alternative to it. However, it must be acknowledged that, as with any democratic view, such approach raises a demos problem. I have examined different solutions that have been proposed to solve such a problem and identified important 
limitations in all of them. In any case, I have argued that those solutions may provide some help when we try to solve one variant of the demos problem that I have called the boundary problem, but they are totally inadequate if what we face is a second variant that I have named the central demos problem, in which the sovereignty of the central demos is at stake. I have claimed that, from a democratic perspective, there is no categorical solution to the central demos problem, and therefore that it is something that we have to live with and extract all the relevant consequences. However, I have identified two different strategies to address the problem and its consequences: an ideal one, based on the goal of reaching democratic consensus or agreement among the peoples involved, and a non-ideal one, the concrete development of which requires much more theoretical work to be done. As it is always the case with democracy, this is just a work in progress.

\section{Acknowledgments}

A preliminary version of this article was presented in a workshop on secessionism held virtually in Barcelona and organized by the Institut d'Estudis d'Autogovern de Catalunya on November 26th, 2020. I thank Ferran Requejo for inviting me to take part in that workshop, as well as the other colleagues who participated and gave me very useful feedback in it. I want to express also my gratitude for all the friends and colleagues with whom I have discussed these ideas, always learning from their suggestions and objections, and to the three anonymous reviewers. Finally, I would like to thank Sydney Olstein for editing the text so quickly and nicely.

\section{Conflict of Interests}

The author declares no conflict of interests.

\section{References}

Abizadeh, A. (2008). Democratic theory and border coercion: No right to unilaterally control your own borders. Political Theory, 36(1), 37-65.

Arrhenius, G. (2005). The boundary problem in democratic theory. In D. B. Renolds (Ed.), Democracy unbound (pp. 14-29). Stockholm University.

Beckman, L. (2014). The subjects of collectively binding decisions: Democratic inclusion and extraterritorial law. Ratio Juris, 27(2), 252-270.

Beran, H. (1984). A liberal theory of secession. Political Studies, 32(1), 21-31.

Bossacoma, P. (2020). Morality and legality of secession: A theory of national self-determination. PalgraveMacmillan.

Brighouse, H., \& Fleurbaey, M. (2010). Democracy and proportionality. Journal of Political Philosophy, 18(2), 137-155.

Brilmayer, L. (1991). Secession and self-determination:
A territorial interpretation. Yale Journal of International Law, 16, 177-202.

Buchanan, A. (1991). Secession: The morality of political divorce from fort Sumter to Lithuania and Quebec. Westview.

Buchanan, A. (1997). Theories of secession. Philosophy and Public Affairs, 26(1), 31-61.

Catala, A. (2017). Secession and distributive justice. Philosophical Studies, 174(2), 529-552.

Christiano, T. (2013). Authority. In E. N. Zalta (Ed.), Stanford encyclopedia of philosophy. https://plato. stanford.edu/entries/authority

Christiano, T. (2015). Democracy. In E. N. Zalta (Ed.), Stanford encyclopedia of philosophy. https://plato. stanford.edu/archives/spr2015/entries/democracy

Dagger, R., \& Lefkowitz, D. (2014). Political obligation. In E. N. Zalta (Ed.), Stanford encyclopedia of philosophy. https://plato.stanford.edu/entries/politicalobligation

Dahl, R. (1970). After the revolution? Authority in a good society. Yale University Press.

Dahl, R. (1991). Democracy and its critics. Yale University Press.

Dalle Mulle, E., \& Serrano, I. (2018). Between a principled and a consequentialist logic: Theory and practice of secession in Catalonia and Scotland. Nations and Nationalism, 25(2), 630-651.

Dryzek, J. (2006). Deliberative global politics: Discourse and democracy in a divided world. Polity.

Goodin, R. (2007). Enfranchising all affected interests, and its alternatives. Philosophy \& Public Affairs, 35(1), 40-68.

Habermas, J. (1992). Between facts and norms: Contributions to a discourse theory of law and democracy. MIT Press.

König-Archibugi, M. (2017). How to diagnose democratic deficits in global politics: The use of the 'all-affected principle.' International Theory, 9(2), 171-202.

Kymlicka, W. (2001). Politics in the vernacular. Oxford University Press.

Lefkowitz, D. (2008). On the foundation of rights to political self-determination. Journal of Social Philosophy, 39(4), 492-511.

Lefkowitz, D. (2018). International law, institutional moral reasoning and secession. Law and Philosophy, 37, 385-413.

López-Guerra, C. (2005). Should expatriates vote? Journal of Political Philosophy, 13(2), 216-234.

Martí, J. L. (2017). Democratic legitimacy and the sources of international law. In S. Besson \& J. d'Aspremont (Eds.), The Oxford handbook of the sources of international law (pp. 724-745). Oxford University Press.

Miller, D. (1998). Secession and the principle of nationality. In M. Moore (Ed.), National self-determination and secession (pp. 62-78). Oxford University Press.

Miller, D. (2003). Liberalism and boundaries: A response to Allen Buchanan. In A. Buchanan \& M. Moore 
(Eds.), States, nations and borders (pp. 262-272). Cambridge University Press.

Moore, M. (1997). On national-self-determination. Political Studies, 45(5), 900-913.

Patten, A. (2014). Equal recognition. Princeton University Press.

Pérez, L. (2021). Theories of the right secession: A republican analysis. Las Torres de Lucca, 10(18), 27-35.

Pérez, L., \& Santjaume, M. (2013). Legalizing secession: The Catalan case. The Journal of Conflictology, 4(2), 3-12.

Pettit, P. (2012). On the people's terms. Cambridge University Press.

Philpott, D. (1995). A defense of self-determination. Ethics, 105(2), 352-385.

Santjaume, M. (2020). Moralism in theories of secession:
A realist perspective. Nations and Nationalism, 26(2), 323-343.

Schumpeter, J. (1942). Capitalism, socialism and democracy. Harper.

Stilz, A. (2018). Territorial sovereignty: A philosophical exploration. Oxford University Press.

Sunstein, C. (1988). Beyond the republican revival. Yale Law Journal, 97, 1538-1590.

Weinstock, D. (2000). Towards a proceduralist theory of secession. Canadian Journal of Law and Jurisprudence, 13, 251-264.

Weinstock, D. (2001). Constitutionalizing the right to secede. The Journal of Political Philosophy, 9(2), 182-203.

Wellman, C. (2005). A theory of secession. Cambridge University Press.

\section{About the Author}

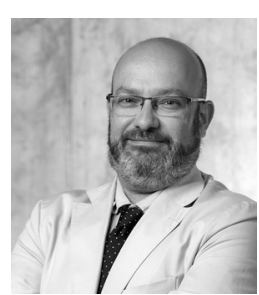

José L. Martí is associate professor of legal and political philosophy at Pompeu Fabra University. His research focuses on republicanism, global governance, legitimacy, deliberative and democratic theory, and the impact of new technologies. He has published several books, including La República Deliberativa (Marcial Pons, 2006), Deliberative Democracy and Its Discontents, co-edited with Samantha Besson (Ashgate, 2006), Legal Republicanism, also co-edited with Samantha Besson (Oxford University Press, 2009), and A Political Philosophy in Public Life, co-authored with Philip Pettit (Princeton University Press, 2010). 